\title{
Pengaruh Infrastruktur Ekonomi dan Sosial terhadap Pertumbuhan Ekonomi Indonesia, 2015-2019
}

\author{
(Effect of Economic and Social Infrastructure on Indonesia's Economic Growth, 2015-2019) \\ Divia Angelina $^{1 *}$, Krismanti Tri Wahyuni ${ }^{2}$ \\ ${ }^{1,2}$ Politeknik Statistika STIS \\ Jalan Otto Iskandardinata No. 64C, Bidara Cina, Jatinegara, Jakarta Timur \\ E-mail: 211709640@stis.ac.id
}

\begin{abstract}
ABSTRAK
Anggaran infrastruktur di Indonesia pada tahun 2015 mengalami peningkatan pesat hingga 62,7\% dibandingkan tahun sebelumnya. Selama lima tahun, angka ini terus tumbuh hingga tahun 2019 meningkat sebesar 62\%. Melonjaknya peningkatan anggaran infrastruktur era pemerintahan Presiden Jokowi dilakukan demi mempercepat pertumbuhan ekonomi di Indonesia. Namun, hingga akhir periode pertama pemerintahannya, sepertiga wilayah di Indonesia masih memiliki pertumbuhan ekonomi di bawah 5\%. Selain itu, hampir 60\% pertumbuhan ekonomi di Indonesia disumbang dari Pulau Jawa. Tujuan dilakukannya penelitian ini yatu untuk menganalisis pengaruh infrastruktur ekonomi dan sosial, yaitu infrastruktur jalan, listrik, air, kesehatan, dan TIK terhadap pertumbuhan ekonomi di Indonesia pada periode 20152019. Analisis yang dilakukan menggunakan regresi data panel dengan metode estimasi Fixed Effect Model SUR. Hasil penelitian menunjukkan bahwa kelima variabel infrastruktur berpengaruh positif dan signifikan terhadap pertumbuhan ekonomi di Indonesia pada tahun 2015-2019.
\end{abstract}

Kata kunci: infrastruktur, pertumbuhan ekonomi, regresi data panel

\begin{abstract}
Compared to the previous period, in 2014, the infrastructure budget in 2015 increased by 62,7\%. For five years, this figure continued to grow until 2019 increased by 62\%. The increase in the infrastructure budget in President Jokowi's administration is to accelerate economic growth in Indonesia. However, until the end of the first period of his reign, a third of Indonesia's territory still had economic growth below 5\%. In addition, almost 60\% of Indonesia's economic growth comes from Java. This study aims to analyze the effect of economic and social infrastructure, namely road, electricity, water, health, and ICT infrastructure on economic growth in Indonesia during the 2015-2019. The analysis using panel data regression with the Fixed Effect Model SUR estimation method. The results showed that the five infrastructure variables had a positive and significant impact on economic growth in Indonesia in 2015-2019.
\end{abstract}

Keywords: infrastructure, economic growth, panel data regression

\section{PENDAHULUAN}

Presiden Jokowi memiliki program prioritas yang disebut dengan Nawacita pada masa pemerintahannya tahun 2015-2019. Pembangunan yang kurang merata terutama di wilayah perbatasan menjadi fokus utama pemerintah melalui pembangunan infrastruktur sebagai salah satu kunci dalam mengejar ketertinggalan. Pada prinsipnya, tercapainya tujuan suatu pembangunan pada kurun waktu tertentu akan menjadi awal dari pembangunan berikutnya. Keberhasilan penyelenggaraan pembangunan suatu wilayah ini dapat dilihat salah satunya dengan indikator pertumbuhan ekonomi. Pertumbuhan ekonomi merupakan proses perubahan kondisi perekonomian secara berkesinambungan yang terjadi di suatu wilayah untuk mencapai keadaan yang lebih baik (Kemenkeu, 2018). Kini di era industri 4.0, pertumbuhan tidak akan mampu mencapai tingkat potensial maksimum tanpa adanya pembangunan infrastruktur yang memadai, efisien, serta berkualitas tinggi. Infrastruktur turut andil sebagai tolak ukur pembangunan nasional karena mengandung 2 dimensi utama yaitu ekonomi dan sosial. Pada buku Infrastructuring: The key to achieving economic growth, productivity, and quality of Life, Samli (2010), dalam jangka pendek, tersedianya infrastruktur mampu mendukung aktivitas pertumbuhan ekonomi.

Menurut Badan Pusat Statistik (2019), dilihat dari distribusi PDRB nominal 2019, 60\% pertumbuhan ekonomi Indonesia 2019 berasal dari Pulau Jawa. Besar persentase ini tidak sebanding dengan luas Pulau Jawa yang hanya sekitar $6,77 \%$ dari luas daratan Indonesia. Tingginya kontribusi pertumbuhan ekonomi ini menandakan bahwa perekonomian di Indonesia masih memiliki ketergantungan pada Pulau Jawa, atau dengan kata lain pertumbuhan ekonomi di Indonesia sangat dipengaruhi oleh pertumbuhan ekonomi Pulau Jawa. 
Jika dilihat dari pertumbuhan ekonominya, sebagian besar provinsi di Indonesia telah mengalami pertumbuhan di atas pertumbuhan ekonomi nasional pada tahun 2019. Namun demikian, masih terdapat sepertiga bagian atau 11 provinsi di Indonesia yang memiliki pertumbuhan ekonomi di bawah 5\%. Menurut Direktur Riset Centre of Reform on Economics (Core) Indonesia, Piter Abdullah (2019), melambatnya pertumbuhan ekonomi di bawah 5\% akan memicu permasalahan sosial yang besar serta tingkat kesejahteraan masyarakat yang akan mengalami penurunan.

Ketidakmerataan pertumbuhan ekonomi ini salah satunya disebabkan oleh tidak meratanya pembangunan infrastruktur di Indonesia, sehingga penting untuk mengkaji anggaran belanja infrastruktur untuk mempercepat penyelenggaraan pembangunan. Menurut buku Informasi APBN (2019), peningkatan anggaran yang paling signifikan terjadi pada awal pemerintahan Presiden Jokowi tahun 2015. Dalam melaksanakan programnya, APBN infrastruktur tahun 2015 mengalami lonjakan hingga tumbuh sebesar 62,7\%. Angka ini terus bertambah hingga tahun 2019, akhir periode pertama pemerintahan Presiden Jokowi. APBN infrastruktur mengalami pertumbuhan sebesar $62 \%$ menjadi 415 triliun rupiah. Selama 5 tahun pemerintahan Presiden Jokowi, ratarata anggaran infrastruktur di Indonesia mencapai 346 triliun rupiah dengan rata-rata kenaikan anggaran infrastruktur sebesar 31,78 triliun rupiah atau sekitar 12,41\% setiap tahunnya. Bila dibandingkan dengan periode sebelumnya, tahun 2010-2014, rata-rata anggaran infrastruktur di Indonesia adalah 131,8 triliun rupiah dengan rata-rata kenaikan anggaran infrastruktur di Indonesia sebesar 14,28 triliun rupiah atau sekitar 16,6\% setiap tahunnya. Jika dijumlah selama satu periode pemerintahan Presiden Jokowi, APBN yang dikeluarkan pemerintah untuk infrastruktur adalah sebesar 1730,3 triliun rupiah. Total anggaran ini meningkat 2,6 kali lipat dibandingkan total APBN infrastruktur periode sebelumnya, tahun 2010-2014 sebesar 659 triliun rupiah.

Menurut Peraturan Presiden RI nomor 38 tahun 2015, infrastruktur merupakan fasilitas teknis, fisik, sistem, perangkat keras, dan lunak untuk melayani masyarakat dan mendukung jaringan struktur agar pertumbuhan ekonomi dan sosial masyarakat dapat berjalan dengan baik. Infrastruktur ekonomi merupakan aset fisik penunjang aktivitas ekonomi baik dalam produksi maupun konsumsi final, meliputi public utilities (telekomunikasi, air minum, listrik), public work serta sektor transportasi (jalan dan sebagainya). Infrastruktur sosial merupakan aset pendukung kesehatan dan keahlian masyarakat, meliputi pendidikan, kesehatan (rumah sakit dan pusat kesehatan), perumahan dan rekreasi. Tersedianya infrastruktur dengan baik memiliki dampak yang kuat dan positif terhadap pertumbuhan ekonomi (Ramirez dan Esfahani, 1999). World Bank (1994) menyebutkan infrastruktur ssebagai roda penggerak kegiatan ekonomi yang menjadi faktor utama dalam percepatan pertumbuhan ekonomi. Minimnya infrastruktur dapat menghambat pertumbuhan ekonomi.

Menurut Todaro dan Smith (2006), pertumbuhan ekonomi merupakan proses peningkatan kapasitas produktif dalam suatu perekonomian secara terus-menerus dan berkesinambungan sepanjang waktu sehingga menghasilkan tingkat pendapatan dan output nasional yang semakin lama semakin besar. Untuk mengukur pertumbuhan ekonomi, para ekonom menggunakan data PDB untuk skala nasional (Mankiw, 2012), dan PDRB untuk skala provinsi atau kabupaten/kota. PRDB merupakan nilai tambah bruto seluruh barang dan jasa akibat berbagai aktivitas ekonomi yang dihasilkan suatu wilayah pada periode tertentu, tanpa memperhatikan apakah faktor produksi dimiliki oleh residen atau non-residen (BPS). Penghitungan pertumbuhan ekonomi dilakukan melalui perkembangan nilai produksi barang dan jasa berdasarkan PDB/PDRB ADHK yang mencerminkan kinerja perekonomian secara menyeluruh di suatu wilayah pada tahun tertentu (tahun dasar) terhadap nilai tahun sebelumnya (BPS).

Infrastruktur merupakan bagian dari modal fisik yang sangat diperlukan dalam pembentukan output agregat. Pertumbuhan dari modal fisik ini diharapkan berperan penting dalam meningkatkan pertumbuhan ekonomi. Penelitian ini mempunyai dua tujuan, yaitu mengetahui gambaran umum perekonomian dan ketersediaan infrastruktur pada level provinsi di Indonesia serta menganalisis besarnya pengaruh pembangunan infrastruktur terhadap pertumbuhan ekonomi di Indonesia pada pemerintahan pertama Presiden Jokowi.

\section{METODE}

\section{Data dan Sumber Data}

Data yang digunakan dalam penelitian menggunakan data sekunder yang diperoleh dari Badan Pusat Statistik (BPS) berupa data tahunan pada periode 2015-2019 pada 34 provinsi di Indonesi, yaitu:
1. Aceh
5. Jambi
2. Sumatera Utara
6. Sumatera Selatan
3. Sumatera Barat
7. Bengkulu
4. Riau
8. Lampung
9. Kep. Bangka Belitung
10. Kepulauan Riau
11. Dki Jakarta
12. Jawa Barat 
13. Jawa Tengah

14. D I Yogyakarta

15. Jawa Timur

16. Banten

17. Bali

18. Nusa Tenggara Barat

19. Nusa Tenggara Timur

20. Kalimantan Barat
21. Kalimantan Tengah

22. Kalimantan Selatan

23. Kalimantan Timur

24. Kalimantan Utara

25. Sulawesi Utara

26. Sulawesi Tengah

27. Sulawesi Selatan

28. Sulawesi Tenggara
29. Gorontalo

30. Sulawesi Barat

31. Maluku

32. Maluku Utara

33. Papua Barat

34. Papua

Tabel 1. Data dan Sumber Data

\begin{tabular}{cccc}
\hline No & Variabel & Satuan & Sumber \\
\hline 1. & PDRB ADHK 2010 & Milyar rupiah & Publikasi Statistik Indonesia \\
2. & Panjang jalan kondisi baik dan sedang & Km & $\begin{array}{c}\text { Publikasi Statistik Transportasi } \\
\text { Darat }\end{array}$ \\
3. & Listrik & GWh & Publikasi Statistik Listrik \\
4. & $\begin{array}{c}\text { Persentase rumah tangga yang memiliki akses terhadap } \\
\text { layanan sumber air minum layak }\end{array}$ & Persen & Publikasi Statistik Indonesia \\
5. & $\begin{array}{c}\text { Fasilitas kesehatan yaitu rumah sakit umum dan } \\
\text { khusus }\end{array}$ & Unit & Publikasi Statistik Indonesia \\
6. & Persentase rumah tangga yang memiliki telepon seluler & Persen & Publikasi Statistik Telekomunikasi \\
\end{tabular}

Produk Domestik Regional Bruto (PDRB) atas dasar harga konstan 2010 yang sudah ditransformasi dengan logaritma natural digunakan sebagai variabel dependen. Selanjutnya variabel independen terdiri dari infrastruktur ekonomi dan infrastruktur sosial. Infrastruktur ekonomi meliputi panjang jalan kondisi baik dan sedang, listrik yang didistribusikan dan persentase rumah tangga yang memiliki telepon seluler. Infrastruktur sosial diproksi dengan menggunakan variabel jumlah fasilitas kesehatan dan persentase rumah tangga yang memiliki akses terhadap layanan sumber air minum layak. Kualitas dari fasilitas kesehatan menurut provinsi tidak dapat dijelaskan dalam penelitian ini karena keterbatasan data.

\section{Metode Analisis}

Pada penelitian ini menggunakan dua jenis analisis data yaitu secara statistik deskriptif dan statistik inferensia. Analisis deskriptif digunakan untuk melihat gambaran umum karakteristik dari pertumbuhan ekonomi dan faktor sosial ekonomi dari infrastruktur di Indonesia pada tahun 2015-2019. Analisis ini disajikan menggunakan grafik untuk mempermudah visualisasi data. Pertumbuhan ekonomi pada analisis ini dihitung dengan rumus:

$$
\text { Pertumbuhan Ekonomi } i_{i t}=\frac{P D R B_{i t}-P D R B_{i ; t-1}}{P D R B_{i ; t-1}} \times 100 \%
$$

Analisis inferensia dilakukan untuk mengetahui variabel-variabel infrastruktur yang berpengaruh terhadap pertumbuhan ekonomi di Indonesia, baik secara ekonomi maupun sosial. Transformasi logaritma natural dilakukan pada variabel dependen dan variabel independen dengan satuan bukan persentase untuk memudahkan interpretasi dalam bentuk elastisitas (persentase perubahan variabel independen terhadap variabel dependen). Dengan kata lain, koefisien regresi pada persamaan (1) menunjukkan pengaruh variabel independen terhadap persentase variabel PDRB atas dasar harga konstan atau sering disebut sebagai pertumbuhan ekonomi.

Pada penelitian ini, metode analisis inferensia yang digunakan adalah regresi data panel. Berikut adalah model awal analisis regresi data panel dalam penelitian:

$$
\operatorname{LnPDRB}_{i t}=\alpha+\beta_{1} \text { LnJalan }_{i t}+\beta_{2} \text { LnListrik }_{i t}+\beta_{3} \text { Air }_{i t}+\beta_{4} \text { LnKesehatan }_{i t}+\beta_{5} \text { TIK }_{i t}+u_{i t}(2)
$$

Keterangan:

$$
\begin{array}{ll}
\operatorname{LnPDRB}_{\text {it }} & \text { : PDRB atas dasar harga konstan } 2010 \text { di provinsi } i \text { pada tahun ke }-t \\
\text { InJalan }_{i t} & \text { : panjang jalan kondisi baik sedang di provinsi } i \text { pada tahun } \mathrm{ke}-t \\
\text { LnListrik }_{i t} & \text { : listrik yang didistribusikan di provinsi i pada tahun ke }-t \\
\text { Air }_{i t} & : \text { persentase rumah tangga yang memiliki akses terhadap layanan sumber air minum layak } \\
& \text { di provinsi } i \text { pada tahun ke }-t \\
\text { LnKesehatan }_{i t} & : \text { rumah sakit di provinsi i pada tahun ke }-t \\
\text { TIK }_{\text {it }} & : \text { persentase rumah tangga yang memiliki telepon seluler di provinsi } i \text { pada tahun ke }-t \\
\alpha & : \text { intercept gabungan }
\end{array}
$$


$\beta_{k} \quad:$ slope variabel independen $\mathrm{ke}-\mathrm{k}, \mathrm{k}=1,2, \ldots, 5$

$u_{i t}$

: error term provinsi $i$ pada tahun $\mathrm{ke}-\mathrm{t}$

$: 1,2, \ldots, 34 ; 34$ provinsi di Indonesia

: $1,2, \ldots, 5$ tahun ; $2015-2019$

Adapun tahapan analisis dalam model regresi data panal adalah sebagai berikut (Baltagi, 2005) :

1. Melakukan estimasi model dengan Common Effects Model (CEM), Fixed Effects Model (FEM), dan Random Effects Model (REM).

2. Menentukan model terbaik dengan membandingkan antarmodel. Penentuan ini menggunakan uji formal yaitu Uji Chow, Uji Hausman, atau Uji Breusch-Pagan LM.

3. Pemeriksaan struktur matriks varians-kovarians jika model yang terpilih adalah model FEM.

4. Uji LM untuk melihat apakah struktur varians kovarians dari residual bersifat heteroskedastik atau homoskedastik.

5. Uji $\lambda_{\text {LM }}$ untuk melihat keberadaan cross-sectional correlation.

6. Uji asumsi klasik

a. Jika menggunakan estimasi OLS, dilakukan uji asumsi normalitas, nonmultikolinieritas, homoskedastisitas, dan nonautokorelasi.

b. Jika FGLS dilakukan uji asumsi normalitas dan nonmultikolinieritas.

7. Uji keberartian model berdasarkan $R$-squared, uji simultan, dan uji parsial.

8. Interpretasi model terbaik.

\section{HASIL DAN PEMBAHASAN}

\section{Gambaran Umum Pertumbuhan Ekonomi dan Infrastruktur}

Pertumbuhan ekonomi menggambarkan kemampuan perekonomian di suatu wilayah. Semakin tinggi pertumbuhan ekonomi di suatu wilayah maka kesejahteraan di wilayah tersebut semakin baik. Berikut gambaran pertumbuhan ekonomi selama periode 2010-2019.

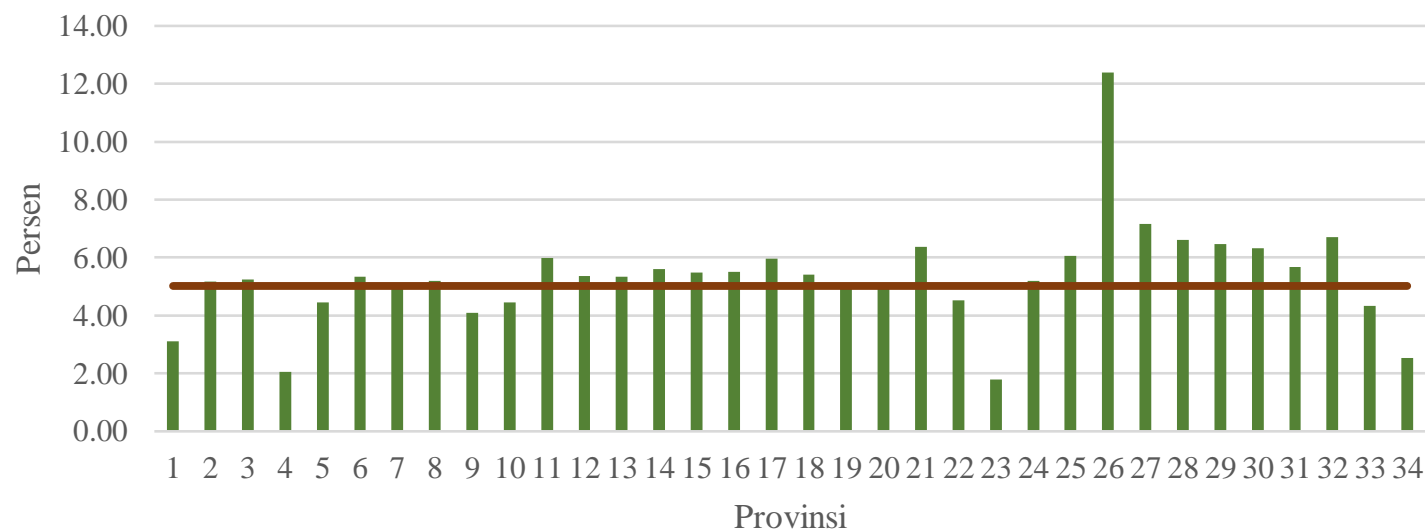

Sumber: Badan Pusat Statistik, diolah

Gambar 1. Rata-rata pertumbuhan ekonomi provinsi dan nasional di Indonesia, 2015-2019 (Persen)

Berdasarkan pertumbuhan ekonomi menurut provinsi di Indonesia, terdapat 9 provinsi yang masih memiliki rata-rata di bawah rata-rata pertumbuhan ekonomi nasional yaitu sebesar 5,03 persen pada tahun 2015-2019. Rata-rata terendah terdapat di Provinsi Kalimantan Timur sebesar 1,79\%. Sebaliknya, rata-rata pertumbuhan ekonomi tertinggi dicapai oleh Provinsi Sulawesi Tengah sebesar 12,39\%.

Untuk mengejar ketertinggalan dari wilayah lain serta mendukung perekonomian Indonesia, Presiden Jokowi pada periode 2015-2019 memfokuskan pembangunan infrastruktur di Indonesia. Pembangunan infrastruktur dilakukan demi pemerataan pembangunan antar daerah, baik secara sosial maupun ekonomi. Hal 
ini dilakukan agar kesejahteraan dapat dirasakan masyarakat merata hingga wilayah pinggiran serta meningkatkan perekonomian seluruh wilayah.

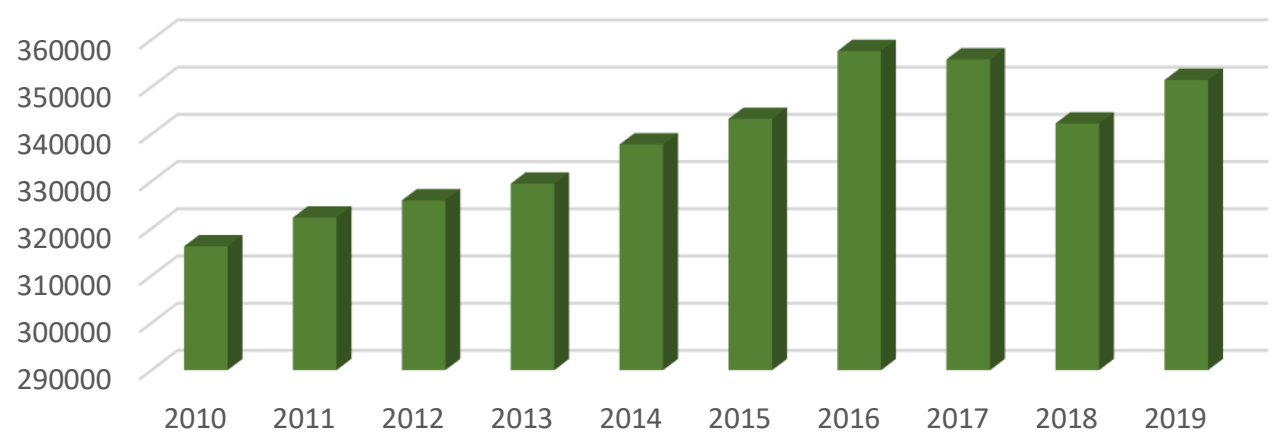

Sumber: Badan Pusat Statistik, diolah

Gambar 2. Panjang jalan kondisi baik sedang di Indonesia, 2010-2019 (kilometer)

Selama 10 tahun, infrastruktur jalan dalam kondisi baik dan sedang cenderung mengalami peningkatan. Pada periode 2010-2014, rata-rata panjang jalan baik sedang adalah $326.377,8 \mathrm{~km}$. Selanjutnya pada periode 2015-2019, yaitu era Presiden Jokowi, rata-rata panjang jalan di Indonesia berfluktuatif namun rata-ratanya meningkat dibandingkan periode sebelumnya menjadi sebesar $350.082,8 \mathrm{~km}$. Infrastruktur jalan yang memiliki kondisi baik sedang terpanjang terjadi pada tahun 2016 sebesar $357.614 \mathrm{~km}$.

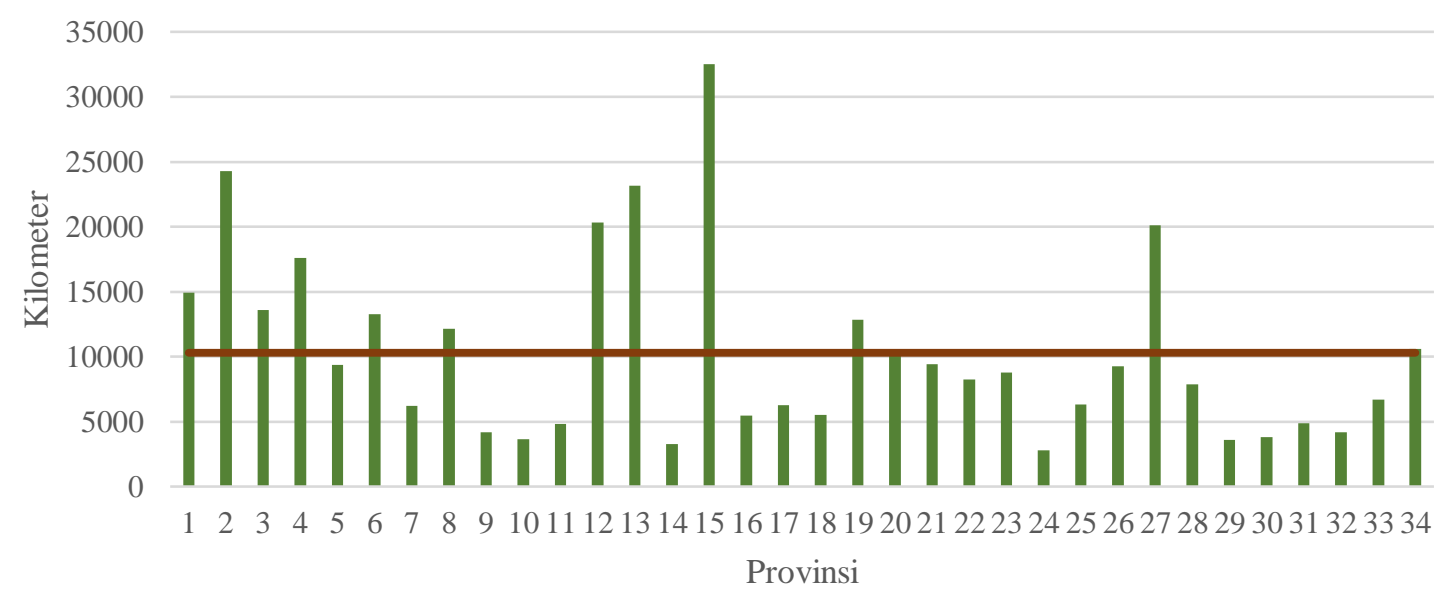

Sumber: Badan Pusat Statistik, diolah

Gambar 3. Rata-rata panjang jalan menurut provinsi dan nasional di Indonesia, 2015-2019 (kilometer)

Dari 34 wilayah di Indonesia, terdapat 12 provinsi yang memiliki panjang jalan di atas rata-rata nasional. Rata-rata jalan kondisi baik dan sedang terpanjang terdapat di Provinsi Jawa Timur dengan panjang 32.492 kilometer. Panjang ini diikuti oleh Provinsi Sumatera Utara dan Jawa Tengah dengan rata-rata panjang berturut-turut 24.295 dan 23.175 kilometer. Sebaliknya, provinsi yang memiliki rata-rata jalan umum kondisi baik dan sedang terpendek dimiliki oleh Provinsi Kalimantan Utara. Namun demikian, karena keterbatasan data, panjang jalan ini tidak termasuk jalan tol. Sehingga, kemungkinan pada provinsi lainnya memiliki panjang jalan tol yang lebih besar dibandingkan jalan umum atau memiliki kondisi jalan yang rusak. 


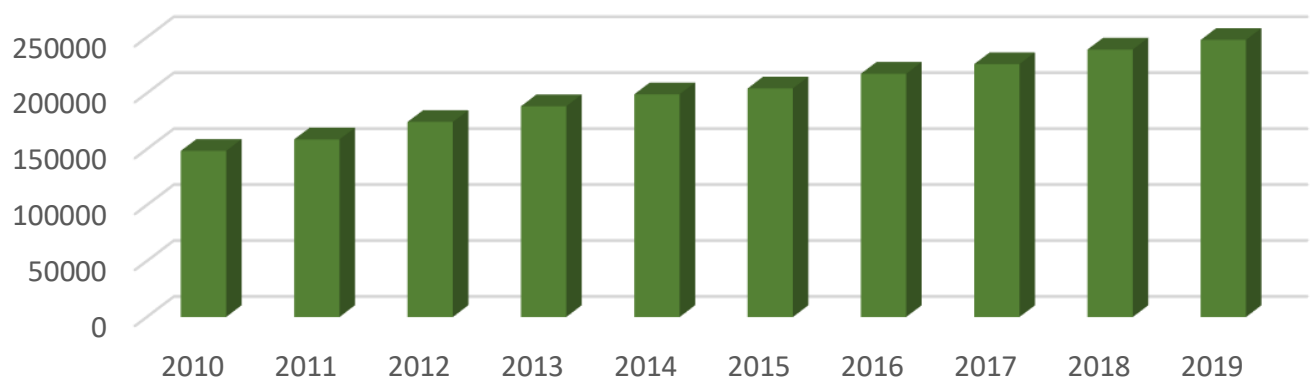

Sumber: Badan Pusat Statistik, diolah

Gambar 4. Listrik yang didistribusikan di Indonesia, 2010-2019 (GWh)

Selama 10 tahun, distribusi listrik di Indonesia meningkat pesat hingga hampir 250 ribu GWh. Tahun 2015-2019, era pemerintahan Presiden Jokowi, rata-rata pasokan listrik yang didistribusikan per tahunnya adalah sebesar 227 ribu Gwh. Dibandingkan dengan periode sebelumnya, tahun 2010-2014, angka ini meningkat $31 \%$, dengan rata-rata listrik yang didistribusikan sebesar 174 ribu GWh.

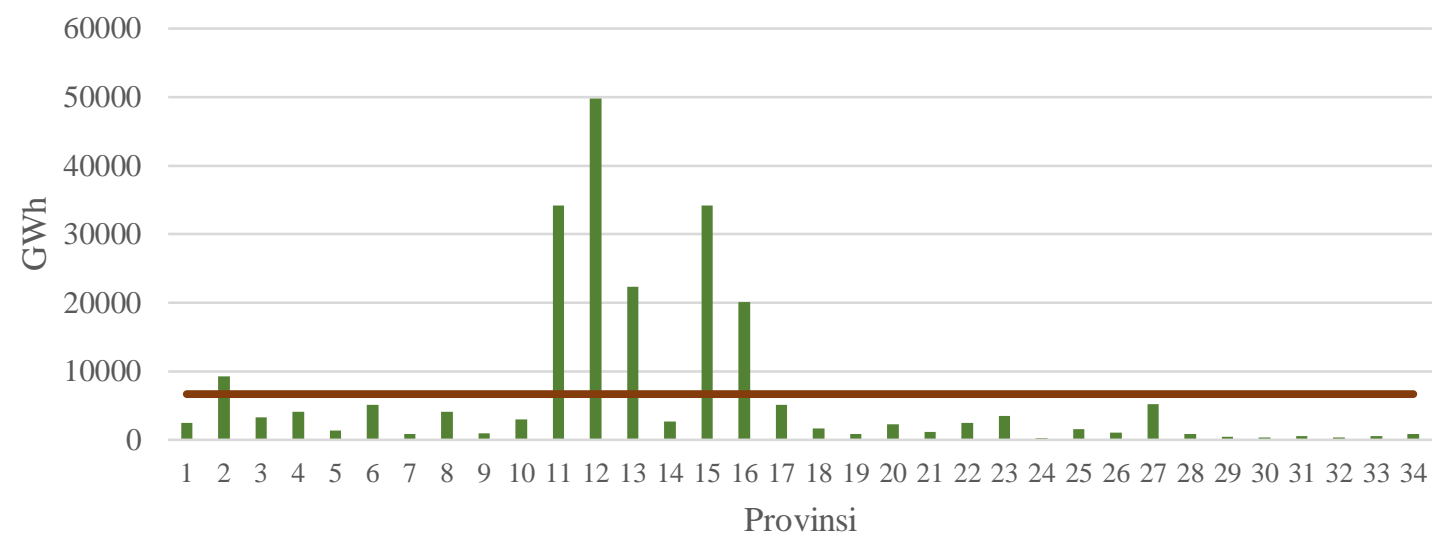

Sumber: Badan Pusat Statistik, diolah

Gambar 5. Rata-rata listrik yang didistribusikan menurut provinsi dan nasional, 2015-2019 (Gwh)

Secara nasional, provinsi dengan rata-rata distribusi listrik tertinggi didominasi provinsi di Pulau Jawa kecuali DI Yogyakarta. Tingginya distribusi ini disebabkan banyaknya penduduk yang tinggal di Pulau Jawa serta banyaknya lapangan pekerjaan, baik perusahaan kecil hingga pabrik industri besar. Pada gambar 5, wilayah yang memiliki rata-rata distribusi listrik tertinggi dimiliki oleh Provinsi Jawa Barat sebesar 49.775 GWh. Nilai ini diikuti oleh Provinsi DKI Jakarta dan Jawa Timur secara berturut-turut sebesar 34.230 dan 34.182 GWh. Sebaliknya, rata-rata distribusi listrik terendah dimiliki Kalimantan Utara dengan nilai $211 \mathrm{GWh}$.

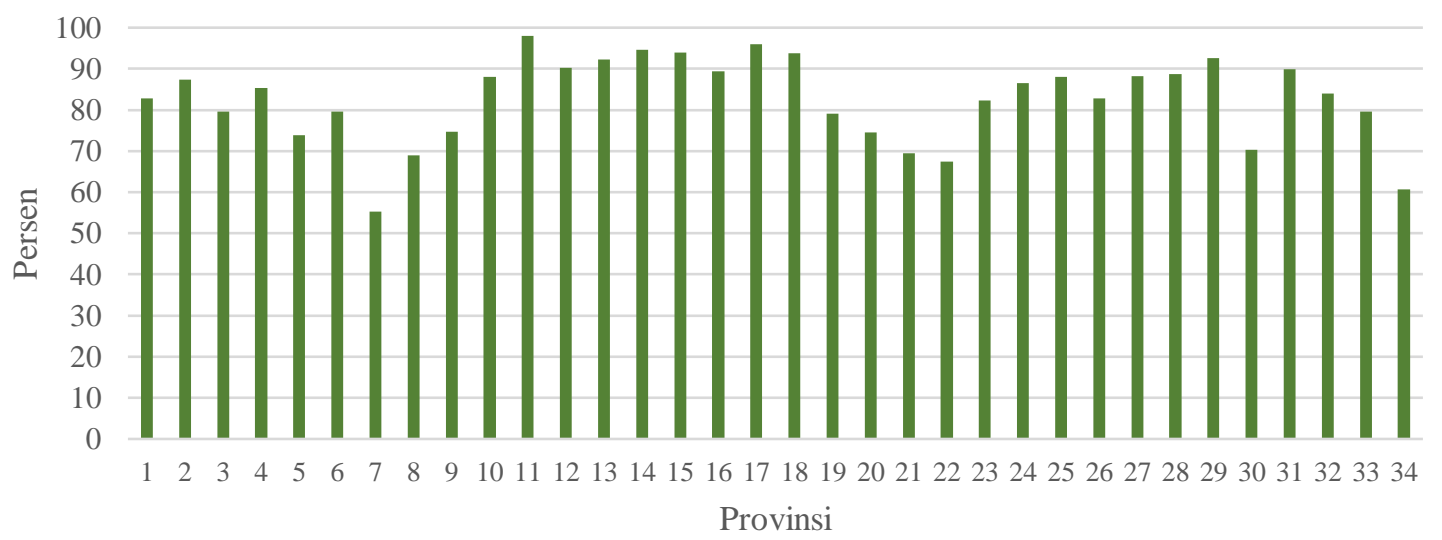

Sumber: Badan Pusat Statistik, diolah

Gambar 6. Rumah tangga yang mengakses air minum layak menurut provinsi di Indonesia, 2015-2019 (\%)

Terlihat bahwa rata-rata air minum layak secara nasional di Indonesia pada periode 2015-2019 adalah sebesar 87,64 persen pada periode 2015-2019. Provinsi yang memiliki rata-rata infrastruktur air minum 
tertinggi dimiliki oleh DKI Jakarta sebesar 98,05\%. Persentase ini diikuti oleh Provinsi Bali dan DI Yogyakarta dengan rata-rata nilai berturut-turut sebesar 95,97 dan 94,54 persen. Sebaliknya, provinsi rata-rata infrastruktur air terendah dimiliki oleh Provinsi Bengkulu dengan nilai 55,25 persen.

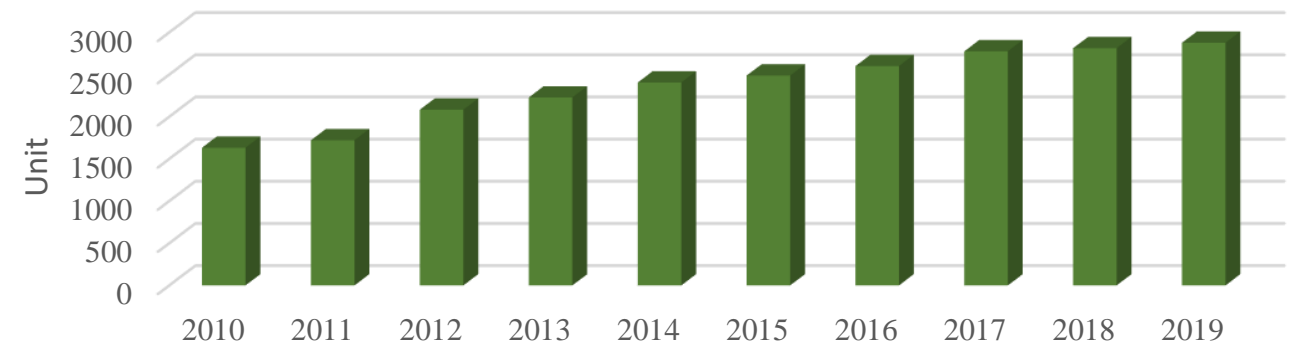

Sumber: Badan Pusat Statistik, diolah

Gambar 7. Jumlah rumah sakit di Indonesia, 2010 - 2019

Selama 10 tahun, jumlah rumah sakit di Indonesia mengalami peningkatan. Pada era pemerintahan Presiden Jokowi, yaitu tahun 2015-2019, rata-rata jumlah rumah sakit di Indonesia setiap tahunnya sebanyak 2711 unit. Angka ini meningkat 35\% dibandingkan era sebelumnya, yaitu tahun 2010-2014, dengan rata-rata jumlah rumah sakit setiap tahunnya sebesar 2014 unit.

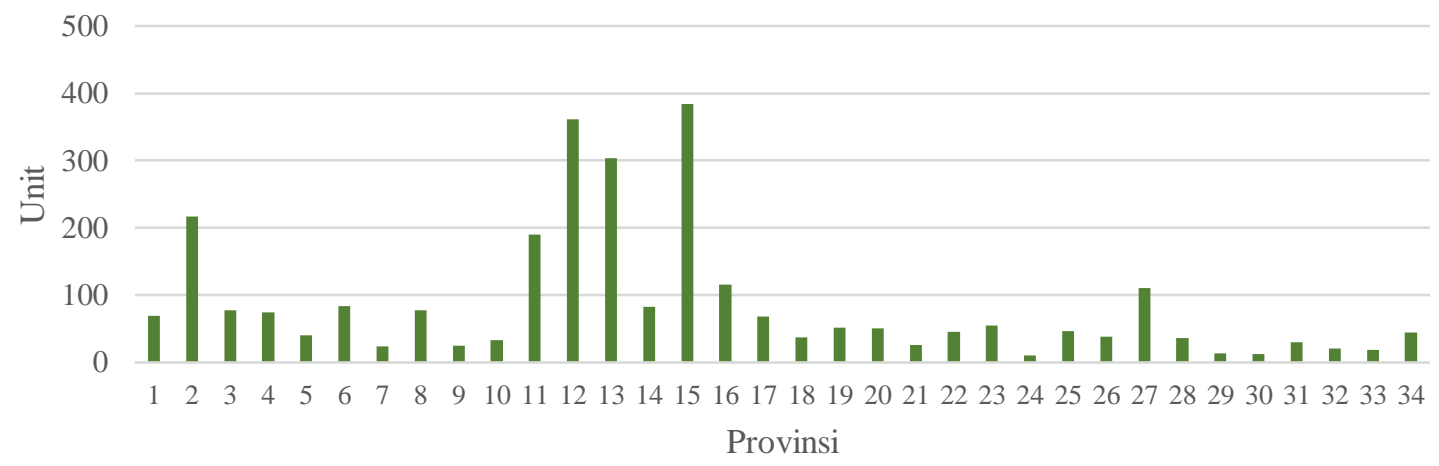

Sumber: Badan Pusat Statistik, diolah

Gambar 8. Jumlah rumah sakit menurut provinsi di Indonesia, 2019

Jumlah rumah sakit tertinggi di Indonesia terdapat di Pulau Jawa dengan total 1.438 unit rumah sakit atau 50\% dari total rumah sakit di Indonesia berada di Pulau Jawa. Provinsi yang memiliki jumlah rumah sakit tertinggi terdapat di Provinsi Jawa Timur, yaitu sebanyak 384 unit. Angka ini diikuti oleh Provinsi Jawa Barat dan Jawa Tengah berturut-turut memiliki 361 dan 304 unit. Sebaliknya, wilayah yang memiliki jumlah rumah sakit terendah dimiliki oleh Provinsi Kalimantan Utara yaitu sebanyak 10 unit.

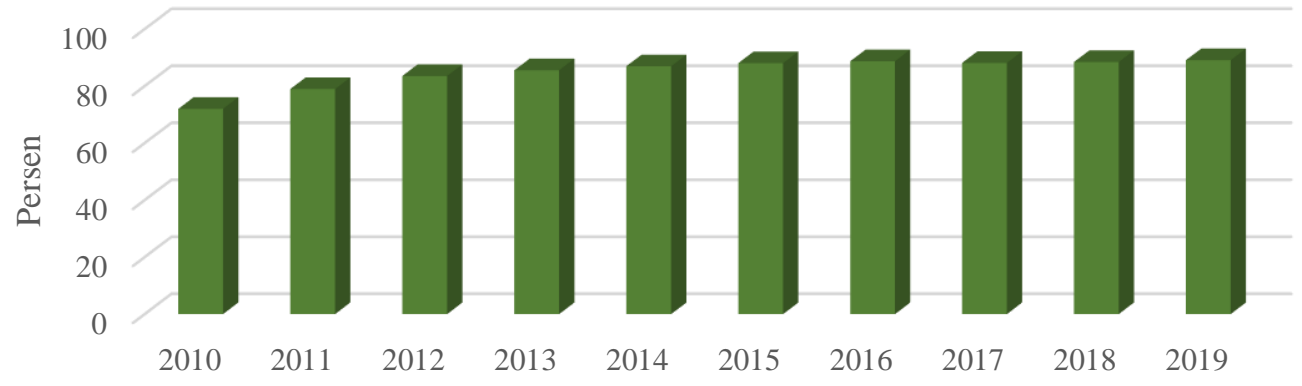

Sumber: Badan Pusat Statistik, diolah

Gambar 9. Persentase rumah tangga yang memiliki telepon seluler di Indonesia, 2010 - 2019

Selama 10 tahun, persentase rumah tangga yang memiliki telepon seluler di Indonesia mengalami peningkatan. Terutama pada era pemerintahan Presiden Jokowi, selama 5 tahun kepemimpinannya, rata-rata 
persentase setiap tahunnya adalah sebesar $88,5 \%$. Angka ini meningkat $7,1 \%$ dibandingkan periode sebelumnya, yaitu tahun 2010-2014, dengan rata-rata persentase rumah tangga yang memiliki telepon seluler di Indonesia setiap tahunnya adalah $81,4 \%$.

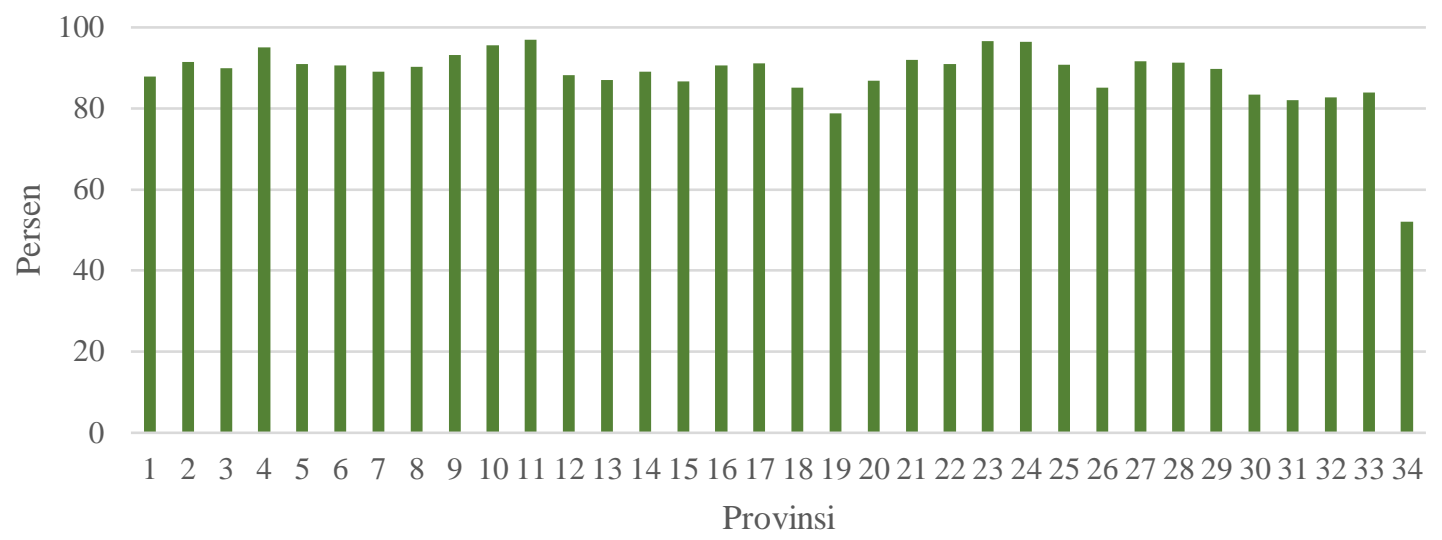

Sumber: Badan Pusat Statistik, diolah

Gambar 10. Rata-rata persentase rumah tangga yang memiliki telepon seluler menurut provinsi, 2015-2019

Tahun 2015-2019, rata-rata rumah tangga menurut provinsi di Indonesia sudah memiliki telepon seluler dengan baik, yaitu mendekati 100\%. Provinsi yang memiliki rata-rata telepon seluler tertinggi selama 5 tahun terdapat di Provinsi DKI Jakarta, yaitu sebanyak sebanyak 96,89 persen. Angka ini diikuti oleh Provinsi Kalimantan Timur dan Kalimantan Utara yang berturut-turut memiliki besar 96,58 dan 96,44 persen.Sebaliknya, wilayah yang memiliki rata-rata telepon seluler terendah dimiliki oleh Provinsi Papua, yaitu sebanyak 52,06 persen.

\section{Pengaruh Infrastruktur terhadap Pertumbuhan Ekonomi}

Untuk memperjelas hubungan variabel infrastruktur dengan pertumbuhan ekonomi, dilakukan pemodelan menggunakan analisis regresi data panel. Berdasarkan hasil pengujian model terbaik data panel, pada uji Chow diperoleh statistik uji sebesar 374,0045 dengan statistik tabel sebesar 1,5254 sehingga tolak $\mathrm{H}_{0}$, menunjukkan model FEM merupakan model yang sesuai. Selanjutnya, karena uji Chow menunjukkan hasil tolak $\mathrm{H}_{0}$ maka dilakukan uji Hausman. Statistik uji Hausman sebesar 26,8972 dengan statistik tabel sebesar 11,0705 yang berarti tolak $\mathrm{H}_{0}$, sehingga dapat disimpulkan model yang tepat adalah model FEM.

Kemudian dilakukan pemeriksaan struktur matriks varians covarians dari residual model FEM. Uji Lagrange Multiplier digunakan untuk menentukan struktur matriks apakah bersifat homoskedastik atau heterokedastik. Berdasarkan hasil pengujian, nilai statistik uji LM sebesar 84 dan nilai $\chi_{0,05}^{2}$ sebesar 47,3999 sehingga tolak $\mathrm{H}_{0}$. Hal ini menunjukkan struktur varians covarians residual bersifat heterokedastik. Selanjutnya menguji apakah struktur varians covarians residual memiliki korelasi antar individunya dengan uji $\lambda_{\text {LM }}$. Hasil pengujian menunjukkan nilai $\lambda_{\text {LM }}$ sebesar 981,9006 dan statistik tabel sebesar 617,2098, sehingga tolak $\mathrm{H}_{0}$, yang berarti bersifat heterokedastik dan terdapat korelasi antarindividu. Hal ini menunjukkan bahwa metode estimasi yang digunakan yaitu Seemingly Unrelated Regression (SUR).

Setelah didapatkan model estimasi terbaik, dilakukan pengujian asumsi klasik. Pengujian normalitas menggunakan uji Jarque-Berra diperoleh $p$-value sebesar 0,0806 lebih besar dari tingkat signifikansi 5\% yaitu gagal tolak H0, yang berarti eror berdistribusi normal dan asumsi terpenuhi. Kemudian dilakukan pengujian non multikolinearitas yang dilihat dari nilai VIF. Hasil VIF diperoleh 5 variabel memiliki nilai kurang dari 10. Hal ini menunjukkan bahwa asumsi non multikolinieritas terpenuhi. Sehingga metode yang digunakan dalam penelitian ini memiliki sifat yang BLUE (Best Linear Unbiased Estimator).

Berdasarkan tabel output dari model terbaik, nilai adjusted $R$-squared yang diperoleh sebesar 0,9995 . Artinya, variabel infrastruktur dalam model mampu menjelaskan keragaman variabel pertumbuhan ekonomi sebesar 99,95\%, sedangkan sisanya dijelaskan variabel lain di luar model. Uji simultan menunjukkan bahwa secara bersama-sama variabel infrastruktur mempengaruhi variabel pertumbuhan ekonomi di Indonesia. Dengan demikian, model ini sudah cukup baik dan dapat dilanjutkan dengan interpretasi hasil.

Dengan memasukkan nilai estimasi parameter yang diperoleh ke persamaan (2), maka diperoleh persamaan hasil regresi sebagai berikut. 


$$
\begin{aligned}
& \operatorname{LnPDRB}_{i t}=\left(6,7702+\mu_{i}\right)+ \text { 0,0862 } \text { lnJalan }_{i t}+0,1893 \text { InListrik }_{i t}+0,0048 \text { Air }_{i t}+ \\
& \text { 0,5281 } \text { lnKesehatan }_{i t}+0,0045 \text { IIK }_{i t}
\end{aligned}
$$

Berdasarkan uji parsial, dengan tingkat signifikansi 5\% terdapat cukup bukti bahwa kelima variabel infrastruktur, yaitu jalan, listrik, air minum, kesehatan, dan TIK berpengaruh signifikan dan positif terhadap pertumbuhan ekonomi. Artinya, bertambahnya infrastruktur akan semakin meningkatkan pertumbuhan ekonomi di Indonesia pada tahun 2015-2019.

Tabel 2. Ringkasan hasil estimasi

\begin{tabular}{cccc}
\hline Parameter & Koefisien & t-Statistik & Prob \\
\hline Cariabel Dependen: Pertumbuhan Ekonomi \\
\hline C (intercept)* & 6,7702 & 29,8998 & 0,0000 \\
lnJalan* & 0,0862 & 5,1575 & 0,0000 \\
lnListrik* & 0,1893 & 7,4268 & 0,0000 \\
Air* & 0,0048 & 5,2721 & 0,0000 \\
LnKesehatan* & 0,5281 & 17,3300 & 0,0000 \\
TIK* & 0,0045 & 3,4162 & 0,0008 \\
\hline \multicolumn{3}{c}{ Adjusted R-Squared } & \multicolumn{3}{c}{0,9995} \\
& F-Statistic & 0,0000 & \\
& Prob (F-Statistic) & &
\end{tabular}

Keterangan: *signifikan pada $\alpha=5 \%$

Variabel logaritma natural panjang jalan yang baik dan sedang memiliki koefisien sebesar 0,0862 , artinya setiap bertambahnya panjang jalan sebesar 1 persen maka akan meningkatkan pertumbuhan ekonomi sebesar 0,0862 persen dengan asumsi variabel lain konstan. Menurut Kwon dalam Duclos, dkk (2013), Irefan dan Adry (2018), dan Samli (2010), pembangunan jalan dengan kuantitas dan kualitas yang baik mampu meningkatkan keefisienan dan keefektifan jalan sehingga mempercepat dan mempermudah mobilitas masyarakat serta barang dengan baik juga.

Variabel logaritma natural jumlah listrik yang didistribusikan memiliki koefisien sebesar 0,1893 , artinya setiap meningkatnya listrik yang didistribusikan sebesar 1 persen akan meningkatkan pertumbuhan ekonomi sebesar 0,1893 persen dengan asumsi variabel lain konstan. Sejalan dengan Maryaningsih, dkk (2014) dan Keusuma dan Suriani (2015) bahwa variabel listrik berpengaruh positif terhadap pertumbuhan ekonomi.

Variabel persentase rumah tangga yang memiliki akses air minum layak memiliki koefisien bernilai 0,0048, artinya setiap meningkatnya persentase rumah tangga yang memiliki akses air minum layak sebesar 1 persen akan meningkatkan pertumbuhan ekonomi sebesar 0,0048 persen dengan asumsi variabel lain konstan. Sesuai Timilsina, dkk (2020), air minum merupakan elemen pendukung infrastruktur terhadap pertumbuhan ekonomi di suatu wilayah.

Variabel logaritma natural jumlah fasilitas kesehatan memiliki koefisien bernilai 0,5281, artinya setiap meningkatnya rumah sakit sebesar 1 persen akan meningkatkan pertumbuhan ekonomi sebesar 0,5281 persen dengan asumsi variabel lain konstan. Sejalan dengan Suripto dan Lestari (2019) bahwa kesehatan berpengaruh signifikan dan positif terhadap PDRB di Indonesia.

Variabel persentase rumah tangga yang memiliki telepon seluler memiliki koefisien bernilai 0,0045 , artinya setiap meningkatnya persentase rumah tangga yang memiliki telepon seluler sebesar 1 persen maka akan meningkatkan pertumbuhan ekonomi sebesar 0,0045 persen dengan asumsi variabel lain konstan. Sejalan dengan penelitian Samli (2005), Andosou (2017), dan Oktavia (2020) bahwa infrastruktur informasi global mempengaruhi pertumbuhan ekonomi negara.

Berdasarkan metode analisis yang terpilih, dapat disimpulkan bahwa terdapat perbedaan karakteristik antarprovinsi yang dipengaruhi pertumbuhan ekonomi selain variabel-variabel yang digunakan, yang disebut sebagai efek individu. Hasil pengolahan menunjukkan bahwa efek individu terbesar dimiliki oleh Provinsi DKI Jakarta. Sedangkan efek individu terkecil terjadi di Provinsi Maluku.

\section{KESIMPULAN}

Pertumbuhan ekonomi di Indonesia tahun 2015-2019, yaitu era pemerintahan Presiden Jokowi, baik secara nasional maupun provinsi mengalami peningkatan. Artinya, produksi barang dan jasa di Indonesia pada tahun 2015-2019 mengalami pertumbuhan. Secara nasional, infrastruktur ekonomi dan sosial setiap tahunnya juga mengalami peningkatan pada tahun 2015-2019, walaupun pembangunan jalan, distribusi listrik, dan 
jumlah rumah sakit di luar Pulau Jawa masih minim. Hal ini dibuktikan dengan terpilihnya Fixed Effect Model dengan adanya efek individu (provinsi) yang berbeda-beda. Berdasarkan model terpilih dengan metode estimasi SUR, semua variabel infrastruktur berpengaruh positif dan signifikan terhadap pertumbuhan ekonomi di Indonesia dengan tingkat keyakinan 5 persen. Penelitian ini menunjukkan peran penting modal fisik infrastruktur dalam pembangunan Indonesia.

\section{DAFTAR PUSTAKA}

Andosou, F Donou. (2017). Education, technologi and Economic growth in Sub Saharan Africa. USA: Departement of Economic \& Finance, John Carrol University.

Badan Pusat Statistik (BPS). Berbagai Edisi. Statistik Indonesia. Jakarta: Badan Pusat Statistik.

Badan Pusat Statistik (BPS). Berbagai Edisi. Statistik Listrik. Jakarta: Badan Pusat Statistik.

Badan Pusat Statistik (BPS). Berbagai Edisi. Statistik Telekomunikasi. Jakarta: Badan Pusat Statistik.

Badan Pusat Statistik (BPS). Berbagai Edisi. Statistik Transportasi Darat. Jakarta: Badan Pusat Statistik.

Baltagi, Badi H. (2005). Econometric Analysis of Panel Data, Third Edition. Chichester: John Wiley \& Sons.

Direktorat Penyusunan APBN. (2019). Informasi Anggaran Pendapatan Belanja Negara 2019. Jakarta.

Duclos, J. Y., Cockburn, J. M., Tiberti, L., \& Dissou, Y. (2013). Infrastructure and economic growth in Asia (p. 148). Springer Nature. ISBN: 978-3-319-03136-1

Irefan, S., \& Adry, M. R. (2018). Pengaruh Infrastruktur terhadap Pertumbuhan Ekonomi di Indonesia. ECOsains: Jurnal Ilmiah Ekonomi dan Pembangunan, 7(1), 57-66.

Kemenkeu. (2018). Seri Ekonomi Makro - Teori Pertumbuhan Ekonomi. https://klc.kemenkeu.go.id/seriekonomi-makro-teori-pertumbuhan-ekonomi/ [29 Maret 2021]

Keusuma dan Suriani. (2015). Pengaruh Pembangunan Infrastruktur Dasar terhadap Pertumbuhan Ekonomi di Indonesia. ECOsains: Jurnal Ilmiah Ekonomi dan Pembangunan, 4(1).

Mankiw, N. Gregory. (2012). Macroeconomics, Eight Edition. New York: Worth Publishers.

Maryaningsih, N., Hermansyah, O., \& Savitri, M. (2014). Pengaruh infrastruktur terhadap pertumbuhan ekonomi Indonesia. Buletin Ekonomi Moneter dan Perbankan, 17(1), 62-98.

Oktavia, T. (2020). Analisis Pengaruh Teknologi Informasi dan Komunikasi (TIK) serta Pendidikan terhadap Pertumbuhan Ekonomi. Prosiding National Simposium \& Conference Ahlimedia 2020. https://doi.org/10.47387/nasca.v1i1.26

Pemerintah Indonesia. (2015). Peraturan Presiden Nomor 38 Tahun 2015 tentang Kerjasama Pemerintah dengan Badan Usaha dalam Penyediaan Infrastruktur. Sekretariat Negara. Jakarta.

Ramírez-Giraldo, M. T., Esfahani, H. S., \& Ramírez-Giraldo, M. T. (1999). Infrastructure and economic growth. Borradores de Economía; No. 123.

Samli, A. C. (2010). Infrastructuring: The key to Achieving Economic Growth, Productivity, and Quality of Life. Springer Science \& Business Media. ISBN: 978-1-4419-7520-1

Suripto, S., \& Lestari, E. D. (2019). Pengaruh Pembangunan Infrastruktur terhadap PDRB di Provinsi Indonesia. Wahana: Jurnal Ekonomi, Manajemen dan Akuntansi, 22(1), 15-27

Timilsina, dkk. (2020). Infrastructure, Economic Growth, and Poverty : A Review. World Bank Group

Todaro, Michael P. dan Stephen C. Smith. (2006). Pembangunan Ekonomi (edisi kesembilan, jilid I). Jakarta: Erlangga.

World Bank. (1994). World Development Report: Infrastructure for Development. New York: Oxford University Press. 